\title{
Zmiany sieci hydrograficznej i zalesienia a melioracje regionu środkowej Obry (centralna Wielkopolska) w świetle danych historycznych i materiału kartograficznego
}

\author{
Changes in the hydrographic network and area under forest \\ in the context of the Middle Obra melioration (central Wielkopolska region), \\ in the light of historical data and cartographic material
}

\author{
IWONA HILDEBRANDT-RADKE, JAN PRZYBYCIN \\ Instytut Geoekologii i Geoinformacji, Uniwersytet im. Adama Mickiewicza, \\ 61-680 Poznań, ul. Dzięgielowa 27; hilde@amu.edu.pl, janprzybycin@wp.pl
}

Zarys treści. W pracy dokonano oceny zmian sieci hydrograficznej dorzecza środkowej Obry poprzez sumowanie obiektów hydrograficznych o charakterze powierzchniowym w kolejnych przedziałach czasowych określanych przez materiał kartograficzny, czyli w latach 1826, 1940 i 2000 oraz porównanie długości liniowych form sieci hydrograficznej na podstawie tego samego materiału z wykorzystaniem metod GIS.

Elementy powierzchniowe zdygitalizowane z materiału kartograficznego - to jeziora i lasy. Elementami liniowymi, które wzięto pod uwagę przy analizie były cieki: kanały, rzeki i rowy melioracyjne.

W wyniku badań stwierdzono, że od drugiej połowy XIX w. przekształcenia objęły niemal cały obszar środkowego dorzecza Obry. W efekcie prac melioracyjnych nastąpiło odwodnienie Łęgu Obrzańskiego i przekształcenie rzek w kanały. Skutkiem działalności rolniczej był zanik 60\% zbiorników wodnych o powierzchni mniejszej niż 1 ha w ciągu ostatnich 200 lat.

Słowa kluczowe: sieć hydrograficzna, region środkowej Obry, materiały kartograficzne, GIS, antropopresja.

\section{Wprowadzenie}

Regulacje koryt rzecznych w Polsce rozpoczęto już w XII stuleciu, nieco powszechniej wykonywano je w XIV i XV, a zintensyfikowano dopiero pod koniec XVIII w. (Winiecki i Drabiński, 1995). Potrzeba odwadniania dolin rzecznych powstała w wyniku zakłócenia cyklu hydrologicznego i podniesienia poziomu wody w dolinach wskutek wycięcia lasów na wysoczyznach (Hładyłowicz, 1932; Kosturkiewicz i Kędziora, 1995). Lesistość Wielkopolski zmniejszała się stopnio- 
wo z 50\% w końcu XIV w. do 41\% w XVI w., 31\% pod koniec XVIII w. i 21\% przed I wojną światową (Hładyłowicz, 1932; Lipiński, 2006).

Według W. Wilgata (1991) w dolinie Warty w okresie od końca X do końca XIX w. poziom wody podniósł się o $3 \mathrm{~m}$, a Sanu o 2-3 m.

Intensywniejszy rozwój melioracji rolnych na ziemiach polskich przypada na wiek XIX. W nim i na początku następnego (lata 1815-1918) najwięcej prac wykonano w Kongresówce, w ówczesnym Poznańskiem, na Pomorzu i na Śląsku (Ostromęcki, 1957). Dalsze ożywienie prac melioracyjnych nastąpiło w latach 1926-1930. Późniejsze lata - to okres kryzysu rolniczego i stagnacji prac melioracyjnych. W skali całego kraju kolejne ożywienie robót melioracyjnych nastąpiło po II wojnie światowej i trwało do lat 1990. Od $1991 \mathrm{r}$. obserwuje się postępujący regres melioracji - z powodu słabej opłacalności produkcji rolnej, a także protestów ekologów (Lipiński, 2006).

Zmiany hydrograficzne w zlewni Obry były przedmiotem wieloletnich badań Katedry Melioracji, Kształtowania Środowiska i Geodezji Uniwersytetu Przyrodniczego (Akademii Rolniczej) w Poznaniu. Badania te dotyczyły głównie współczesnej melioracji rzeki nizinnej oraz funkcjonowania spółek wodnych na terenie Wielkopolski (Bykowski i inni, 2008; Bykowski i Napierała, 2010; Bykowski i Przybyła, 2010). Aspekt historycznych melioracji doliny Obry podejmowali między innymi Cz. Przybyła (2008) oraz A. Kaniecki i D. Brychcy (2010).

Melioracja regionu środkowej Obry rozpoczęła się w drugiej połowie XVIII wieku, a nasiliła się w XIX. Dla tego przedziału czasowego dostępny jest materiał kartograficzny w postaci map topograficznych, a dla późniejszych okresów również map tematycznych, które umożliwiają analizę czasoprzestrzenną zmian sieci hydrograficznej oraz zalesienia wpływającego na stany wody (Dynowska, 1988; Kaniecki, 2007; Graf i inni, 2008).

\section{Cel pracy}

Głównym celem pracy jest ocena zmian sieci hydrograficznej zlewni środkowej Obry poprzez sumowanie obiektów hydrograficznych o charakterze powierzchniowym w kolejnych przedziałach czasowych wymuszonych przez dostępny materiał kartograficzny oraz porównanie długości liniowych form sieci hydrograficznej na podstawie tych samych materiałów. Autorzy podjęli próbę oszacowania stopnia, w jakim człowiek zmieniał sieć hydrograficzną obszaru w latach 1826, 1940 i 2000.

Na podstawie tego samego materiału dokumentacyjnego dokonano również analizy zmian zalesienia jako czynnika naturalnej retencji, spowalniającego spływ powierzchniowy wody opadowej i przez to ograniczającego w znacznym stopniu wahania wodostanów badanej sieci hydrograficznej.

W przypadku zmian hydrograficznych elementami powierzchniowymi zdygitalizowanymi z materiału kartograficznego sa jeziora i mniejsze zbiorniki 
wodne. Obiekty liniowe, które uwzględniono w analizie - to kanały, rzeki i rowy melioracyjne.

\section{Charakterystyka badanego obszaru}

W podziale mezoregionalnym badany obszar obejmuje oprócz Doliny Środkowej Obry (fragment Pradoliny Warciańsko-Obrzańskiej) Pojezierze Sławskie, Pojezierze Krzywińskie i Równinę Kościańską, a w południowej części fragment Wysoczyzny Leszczyńskiej (Kondracki, 2002). Rozciąga się od 16²3'40" do 1649'58" długości geograficznej wschodniej i od 5153'57” do 52 09'39" szerokości geograficznej północnej. Ma w przybliżeniu wymiary 30 na 29,15 km i ogólną powierzchnię $874,35 \mathrm{~km}^{2}$ (ryc. 1).

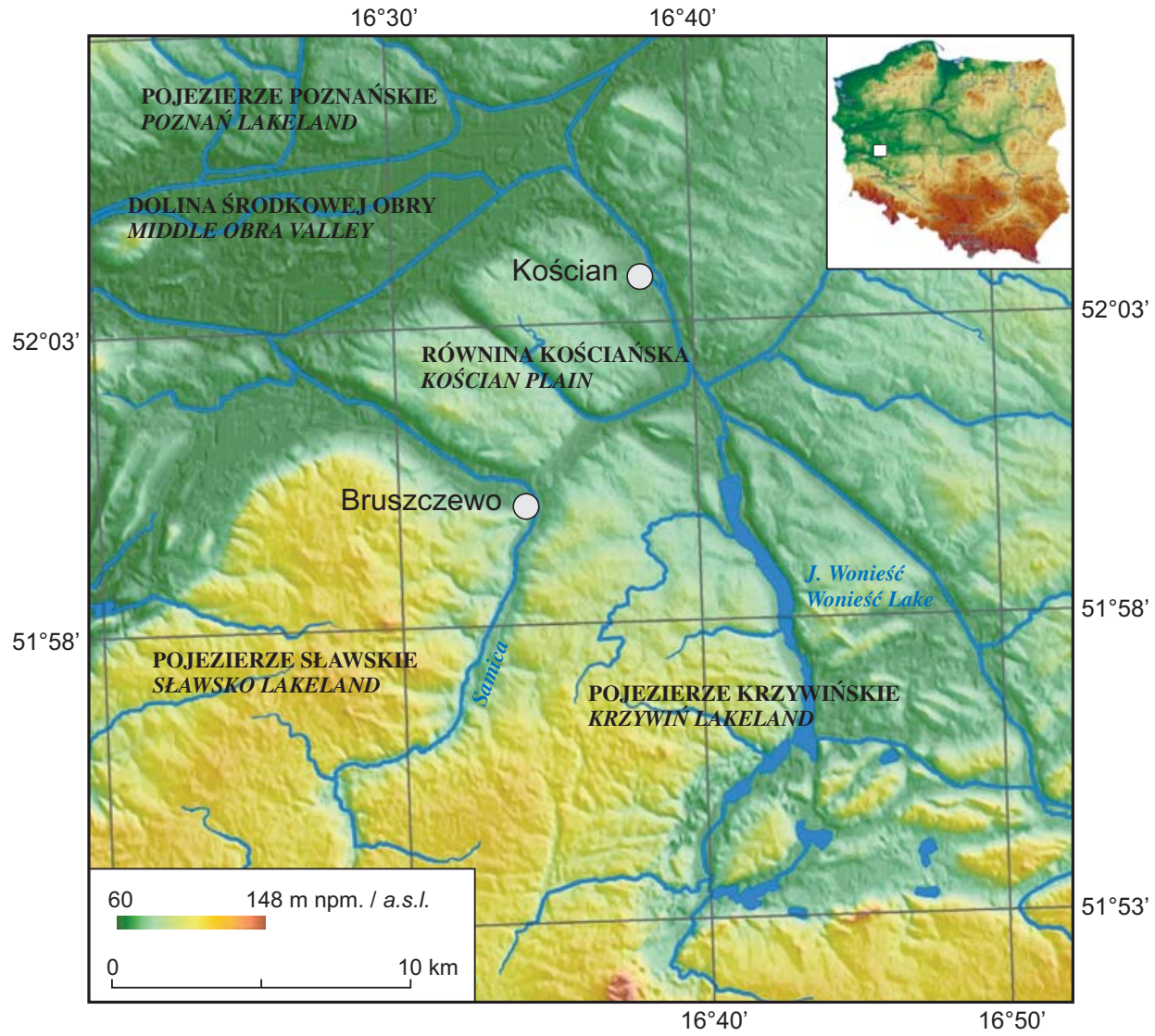

Ryc. 1. Położenie obszaru badań z podziałem na regiony fizycznogeograficzne na podkładzie mapy hipsometrycznej utworzonej na podstawie Vmap Level2

Location of the research area against the background of the division into physico-geographical regions on a hypsometric map elaborated on the basis of Vmap Level2 
Ukształtowanie terenu związane jest z fazą leszczyńską zlodowacenia Wisły. Opisywany obszar charakteryzuje występowanie ciągów wysoczyzn morenowych przyjmujących formę wysp, poprzecinanych obniżeniami dolinnymi powstałymi na skutek przepływu wód fluwioglacjalnych ostatniego zlodowacenia. Wysokości bezwzględne zawierają się w granicach 60-135 m npm.

Wyspy wysoczyznowe przykryte są warstwą gliny o miąższości do około $5 \mathrm{~m}$. W obrębie gliny występują tunele i szczeliny powstałe w wyniku erozji wód glacjofluwialnych. Zarówno te szczeliny, jak i powierzchnia gliny przykryte są nadkładem osadów ablacyjnych o miąższości kilku metrów (Krygowski, 1961, 1972).

Dużą rolę w formowaniu zaplecza leszczyńskiej strefy marginalnej odegrały również wody subglacjalne i inglacjalne. $\mathrm{Z}$ pierwszymi związane jest powstanie licznych rynien i niekiedy towarzyszących im ozów, z drugimi natomiast zespołów form kemowych (pagórków, stoliw i półek) (Krygowski, 1961, 1972).

Największym obniżeniem jest obrzański fragment Pradoliny WarszawskoBerlińskiej o przebiegu z północnego wschodu na południowy zachód. Jest to rozległe, podłużne obniżenie o zmiennej szerokości. Powstało jako droga odpływu wód fluwioglacjalnych w kierunku zachodnim, w fazie poznańskiej ostatniego zlodowacenia. Na badanym odcinku opisywany fragment pradoliny nosi nazwę Doliny Środkowej Obry.

Dolina ta obejmuje zatorfione obniżenie pomiędzy doliną Warty a Kotliną Kargowską. Wysoczyzny sąsiadujące z nią od północy i południa są położone zaledwie o 7-10 m wyżej. Naturalne cieki Doliny Środkowej Obry zostały zmeliorowane kanałami, do których skierowano wody Mogilnicy i górnego odcinka Obry. Pierwotnie występujący tu dział wodny na wysokości $70 \mathrm{~m}$ npm. został przerwany, a wody cieków zbifurkowane w dwóch kierunkach: zachodnim i wschodnim. Kanały Północny i Środkowy kierują wody Obry i Mogilnicy do rynny zbąszyńskiej, natomiast Kanał Południowy kieruje część wód Obry do Obrzycy i dalej do Odry. Pozostała część wód Obry i Mogilnicy spływa do Warty Kanałem Mosińskim (Mapa hydrograficzna, 2001; Paluch, 2006).

Południową część badanego terenu pokrywają wzgórza moren czołowych fazy leszczyńskiej zlodowacenia północnopolskiego (Wisły).

\section{Charakterystyka i przygotowanie materiału kartograficznego}

\section{Wojskowe zdjęcia topograficzne (Urmeßtischblätter) z 1826 r.}

Idea narysowania dokładnej, jednolitej mapy Królestwa Pruskiego powstała po wojnach napoleońskich i okupacji Prus przez Francję w latach 1806-1815. Pracami zajął się pruski Sztab Generalny. Urmeßtischblätter - to pierwsze mapy topograficzne opracowane w terenie. Żadna wcześniejsza mapa tych obszarów nie była tak dokładna. Na arkuszach map w skali 1:25 000 po raz pierwszy szczegółowo przedstawiono ukształtowanie terenu, jeziora i stawy, rzeki i kana- 
ły, sieć dróg, lasy, bardzo dokładnie obrysowano zabudowę - nawet pojedyncze budynki. Każda z map sygnowana jest nazwiskiem kartografa, ze stopniem i jednostką wojskową.

Zostały one zeskanowane w rozdzielczości 400 dpi w jednobitowej palecie barwnej (kolor czarno-biały). Mają siatkę minutową. Do wykreślenia map użyto nowego systemu kartograficznego zaproponowanego przez Müfflinga, który był oparty na odwzorowaniu wielościennym. W odwzorowaniu Müfflinga odcinki o długości i szerokości 1. stopnia (Grad-Abteilung) rzutowane były na oddzielne płaszczyzny, styczne do elipsoidy w środkowym punkcie danego odcinka. Z racji zbyt dużych wielkości arkusza w skali 1:25 000 odcinek stopniowy podzielony został na 10 pasów (Bande I-X) i 6 słupów (Blatt 1-6).

Mapy te pochodzą z Państwowej Biblioteki w Berlinie - Fundacji Pruskiego Dziedzictwa Kulturalnego (Staatsbibliothek zu Berlin - Preußischer Kulturbesitz). Wykorzystano 9 arkuszy oznaczonych sygnaturami: 2129 (nowe oznaczenie 3864) Wielichowo; 2130 (3865) Konojad; 2131 (3866) Czempiń; 2196 (3964) Polnische Wilke (Wilkowo Polskie); 2197 (3965) Kosten (Kościan); 2198 (3966) Choryn; 2266 (4064) Luschwitz (Włoszakowice); 2267 (4065) Leipe (Lipno) i 2268 (4066) Storchnest (Osieczna).

Urmeßtischblätter nie mają legendy. Jej brak i czarno-biały obraz utrudniały interpretację niektórych elementów.

\section{Mapy topograficzne w skali 1:25 $000 \mathrm{z} 1940 \mathrm{r}$.}

Messtischblatty - zdjęcia stolikowe czyli mapy w skali 1:25 000 zaczęto opracowywać już w 1877 r., w późniejszych latach uaktualniano starsze wydania. Użyte w pracy arkusze pochodzą z lat 1940-1944 i wydane zostały przez niemiecki urząd - Reichsamt für Landesaufnahme, jako uaktualnienia map z 1892 r. Odwzorowanie wielościenne zastąpiono tu w 1927 r. odwzorowaniem Gaussa-Krügera. Mapy są czarno-białe, mają siatkę kilometrową i bardzo rozbudowaną legendę.

Arkusze zostały zeskanowane w rozdzielczości 300 dpi. Wykorzystano arkusze o następujących godłach: 3864 Wielichowo (wydana w 1940 r.); 3865 Konojad (1940 r.); 3866 Czempiń (1940 r.); 3964 Polnische Wilke (1944 r.); 3965 Kosten (1940 r.); 3966 Choryn (1940 r.); 4064 Luschwitz (1940 r.); 4065 Leipe (1940 r.); 4066 Storchnest (1940 r.).

\section{Mapy topograficzne w skali 1:25 000 z 1982 r.}

Arkusze wykorzystane w pracy zostały opracowane w Okręgowym Przedsiębiorstwie Geodezyjno-Kartograficznym w Poznaniu w 1982 r. na podstawie map w skali 1:10 000 z lat 1976-1980. Wykonano je w Państwowym Układzie Współrzędnych Geodezyjnych „1965”. Wszystkie wykorzystane arkusze leżą w strefie IV PUWG 1965 i zostały odwzorowane na elipsoidzie Krassowskiego. Dla tej 
strefy zastosowano odwzorowanie quasistereograficzne (Roussilhe'a). Wykonane są w czterokolorowej palecie barw. Zeskanowano je do kolorowych rastrów w rozdzielczości 72 dpi. Użyto arkuszy oznaczonych godłami: 432.21 - Wielichowo; 432.22 - Kościan; 432.23 - Śmigiel; 432.24 - Stare Bojanowo; 432.41 - Włoszakowice; 432.42 - Osieczna.

\section{Mapy hydrograficzne w skali 1:50 000}

Mapy hydrograficzne zostały utworzone przez firmy Geokart i Geomat dla Głównego Urzędu Geodezji i Kartografii jako uaktualnienie wcześniej wydanych map hydrograficznych 1:50 $000,1965 ”$. Aktualność topograficzna tych map to rok 2001, arkusza Leszno-Północ - 2003. Sporządzono je w Państwowym Układzie Współrzędnych Geodezyjnych „1992”, na elipsoidzie GRS-80 w odwzorowaniu Gaussa-Krügera. Są wielobarwne i jako takie zostały zeskanowane do rastrów w rozdzielczości 300 dpi.

Wykorzystano 6 arkuszy tych map: N-33-141-D - Rakoniewice; N-33-142-C - Kościan; N-33-142-D - Czempiń; M-33-9-B - Włoszakowice; M-33-10-A Leszno-Północ; M-33-10-B - Krzywiń.

\section{Mapa topograficzna w skali 1:50 $000 \mathrm{z} 1998 \mathrm{r}$.}

Z racji słabej jakości i zbyt małej skali mapa ta była użyta do dygitalizacji pasa o około 1-kilometrowej szerokości w północnej i wschodniej części obszaru, tam gdzie brakowało arkuszy map topograficznych w skali 1:25 000. Wersja rastrowa tej mapy była kolorowa i miała rozdzielczość 72 dpi. Została wykonana w Państwowym Układzie Współrzędnych Geodezyjnych „1992”, a jej aktualność topograficzna to rok 1998.

Wykorzystano 9 arkuszy: N-33-141-D - Rakoniewice; N-33-142-C - Kościan; N-33-142-D - Czempiń; M-33-9-B - Włoszakowice; M-33-10-A - Leszno-Pó1noc; M-33-10-B - Krzywiń. Pozyskane mapy były już połączone w jeden plik, a raster zarejestrowany w PUWG 1992.

\section{Mapa wektorowa poziomu 2 (V-map Level 2)}

V-map Level 2 stanowi cyfrowy odpowiednik mapy topograficznej w skali 1:50 000. Została utworzona na podstawie map analogowych przez Służbę Geograficzną Wojska Polskiego. Jest numeryczną bazą danych geometrycznych, opracowaną zgodnie ze standardami NATO, zapisaną w modelu wektorowym i uzupełnioną o bazę danych opisowych o obiektach oraz dodatkowo atrybuty i wartości tych atrybutów. Sporządzono ją w geodezyjnym układzie odniesienia WGS 84, w odwzorowaniu UTM. Stan aktualności to lata 2000-2002. Składa się z kilkunastu kategorii tematycznych, takich jak: aeronautyka, granice, kultura, hydrografia, przemysł, roślinność, rzeźba terenu i transport. 
Poszczególne cyfrowe arkusze map odpowiadają połączonym parami arkuszom map w skali 1:50 000. W pracy wykorzystano następujące arkusze V-mapy: n33141ab; n33141cd; n33142ab; n33142cd; m33009ab; m33010ab;

\section{Wektoryzacja map}

Do opracowania danych użyto programu ArcGIS wersja 9.0. firmy ESRI. Pierwszym etapem pracy była rejestracja rastrów polegająca na nadaniu narożnikom zeskanowanych map współrzędnych odczytanych z ramki. Ze względu na to, że różne rodzaje map były odwzorowane w innych układach współrzędnych, dokonano wyboru jednego wspólnego układu dla wszystkich map i zarejestrowano je po wcześniejszym przeliczeniu współrzędnych pomiędzy różnymi układami. Jako wspólny układ wybrano PUWG „1992”. W pierwszej kolejności przeliczono współrzędne wszystkich map topograficznych w skali 1:25 000 z układu PUWG „1965”, posługując się programem Transform 2.5.1 autorstwa Edwarda Zadorskiego. Przeliczone współrzędne użyto do rejestracji w programie ArcGIS. Kolejne mapy rejestrowano metodą punktów kontrolnych. Metoda ta polega na wskazaniu na rejestrowanej mapie punktu charakterystycznego (np. skrzyżowania dróg, kościoła, mostu, punktu wysokościowego) i ponownego wskazania tego samego punktu na mapie uprzednio zarejestrowanej. W ten sposób rejestrowany punkt przyjmuje odpowiednie współrzędne. Do dobrego zarejestrowania potrzeba minimum 4 takich punktów, znajdujących się w różnych częściach mapy. Metoda ta jest szczególnie ważna i często niezastąpiona przy georeferencji map, dla których nie znamy układu odniesienia lub uniemożliwiona jest transformacja współrzędnych do innego układu. W pracy tą metodą rejestrowano mapy historyczne z 1826 oraz mapy z 1940 r. Mapa topograficzna z 1998 r. miała już georeferencję w układzie „1992”. Mapy hydrograficzne zarejestrowano metodą nadania rogom mapy współrzędnych geograficznych odczytanych z mapy. V-mapy jako mapy wektorowe nie wymagały rejestracji.

Kolejnym etapem pracy było przygotowanie odpowiednich pustych plików wektorowych (.shp). Na potrzeby pracy niektóre z nich wzbogacono o dodatkowe atrybuty opisujące obiekty (tab. 1). Następny etap - to wektoryzacja ekranowa, czyli obrysowywanie poszczególnych elementów map rastrowych za pomocą programu typu GIS. W tym przypadku był to ArcMap - wchodzący w skład ArcInfo.

W ten sposób utworzonych zostało 17 warstw tematycznych wzbogaconych atrybutami (w opracowaniu wykorzystano niektóre). Przed kolejnym etapem niezbędne okazało się przetransformowanie wszystkich utworzonych warstw do układu PUWG „1965”. Posłużono się narzędziem „Project”, wchodzącym w skład aplikacji ArcToolbox ArcInfo. Zamiana układu współrzędnych umożliwiła wyświetlenie granic obszaru badań i poszczególnych wektorów bez przesunięć co było istotne w późniejszej pracy i w trakcie użycia narzędzi analitycznych. Po skończonej dygitalizacji warstwy zostały włączone w nowo utworzoną bazę 
danych za pomocą aplikacji ArcCatalog. Dzięki temu poszczególnym warstwom zostały przypisane dodatkowe atrybuty: dla warstw liniowych - Shape Length (długość obiektu), a dla warstw poligonowych - Shape_Length i Shape_Area (powierzchnia obiektu). Każdy z rekordów tabeli opisujących dany obiekt warstwy wektorowej otrzymał w ten sposób obliczoną długość lub/i powierzchnię wyrażoną w jednostkach mapy (metrach). Narzędzie Statistics w ArcCatalogu umożliwiło zsumowanie wartości rekordów całych warstw lub tylko wyselekcjonowanych wartością odpowiedniego atrybutu. Wyniki przepisano do arkusza kalkulacyjnego Excel.

Obliczenia wykorzystane w części wynikowej pracy zostały wykonane za pomocą arkusza Excel. Program ten posłużył również do przygotowania wykresów.

Mapy wynikowe (ryc. 2-5) zostały utworzone w programie ArcMap. Wszystkie warstwy wektorowe map tematycznych pochodzą z dygitalizacji map rastrowych.

Tabela 1. Nazwy i typy warstw wektorowych wykorzystanych w pracy

Names and types of vector layers applied in the work

\begin{tabular}{|c|c|c|c|}
\hline $\begin{array}{c}\text { Nazwa pliku } \\
\text { shape } \\
\text { Filename shape }\end{array}$ & $\begin{array}{l}\text { Typ geometrii } \\
\text { Geometry type }\end{array}$ & $\begin{array}{l}\text { Dodatkowe atry- } \\
\text { buty opisowe } \\
\text { Additional } \\
\text { descriptive attri- } \\
\text { butes }\end{array}$ & $\begin{array}{l}\text { Źródło mapy } \\
\text { wektorowej } \\
\text { The source of the } \\
\text { vector map }\end{array}$ \\
\hline 1826drogi & linia & ID & dygitalizacja \\
\hline 1826jeziora & poligon & nazwa & dygitalizacja \\
\hline 1826kanaly & linia & ID, nazwa & dygitalizacja \\
\hline 1826lasy & poligon & - & dygitalizacja \\
\hline 1826zabudowa & poligon & - & dygitalizacja \\
\hline 1940drogi & linia & klasa & dygitalizacja \\
\hline 1940jeziora & poligon & nazwa & dygitalizacja \\
\hline 1940kanaly & linia & rodzaj & dygitalizacja \\
\hline 1940kolej & linia & rodzaj & dygitalizacja \\
\hline 1940lasy & poligon & - & dygitalizacja \\
\hline 1940wyrobiska & poligon & typ & dygitalizacja \\
\hline 1940zabudowa & poligon & - & dygitalizacja \\
\hline 2000drogi & linia & USE & V-map Level2 \\
\hline 2000jeziora & poligon & nazwa & dygitalizacja \\
\hline 2000kanaly & linia & ID & dygitalizacja \\
\hline 2000kolej & linia & RGC & V-map Level2 \\
\hline 2000lasy & poligon & - & dygitalizacja \\
\hline 2000wyrobiska & poligon & typ & dygitalizacja \\
\hline 2000zabudowa & poligon & - & dygitalizacja \\
\hline
\end{tabular}




\section{Historia melioracji regionu środkowej Obry}

Zlewnia Obry, której powierzchnia wynosi 7076 km², ma specyficzny charakter, gdyż odpływ wód, jak wspomniano wcześniej, odbywa się w trzech kierunkach: w kierunku wschodnim do Warty koło Mosiny, w zachodnim - do Warty pod Cigacicami, oraz północnym do Warty pod Skwierzyną.

Przed około 250 laty główna część doliny Obry, tzw. Wielki Łęg Obrzański, stanowiła niedostępne mokradła, wśród których suche połacie stanowiły piaszczyste wzniesienia. Łęg ten w czasie zahamowania odpływu stawał się jeziorem, do którego spływały wody z otaczających go wysoczyzn oraz górnej części zlewni Obry.

Z. Hilczerówna (1967), powołując się na źródła historyczne - głównie mapy i dawne opisy tego terenu z XVIII i początków XIX w., jak również pojedyncze źródła XVII-wieczne - podjęła próbę opisu dorzecza Obry. „Na odcinku pradoliny wody Obry rozlewały się na szerokiej przestrzeni i tworzyły płytkie, pozarastane trzciną jeziora. Koryto rzeki zanika w bagnach po wejściu do pradoliny w okolicach Bonikowa. Podobnie Samica w pradolinie zatraca swój bieg. Koryto Obry zaznacza się dopiero od połączenia z Mogilnicą i dalej na zachód do Ziemina" (Hilczerówna, 1967; Dynowska, 1988). Nazewnictwo XVIII-wieczne podaje określenia, które potwierdzają silne zabagnienie tego obszaru: „Bagno Ziemin”, „Nader wielkie bagno Obry”. Mapa Freudenhammera z XVII w. przedstawia niektóre odcinki Obry jako duże obszary błotne czy nawet wydłużone jeziora (Hilczerówna, 1967).

Obra w tych okolicach tworzyła wielkie rozlewiska i podlegała ciągłym wylewom. Z. Hilczerówna (1967, s. 39) przywołuje wymowny opis Wawrzyńca Surowieckiego z dzieła pt. O rzekach $i$ sptywach krajów Księstwa Warszawskiego z roku 1861: „Nie masz rzeki, która by wylewami swymi tyle czyniła szkody krajowi naszemu, ile czyni Obra w departamencie poznańskim; ta niszcząc wiele mil kwadratowych i dochody od wielu milionów kapitału należy słusznie do licznych tych plag, które cały naród dotykają. Bez koryta, bez spadku, wody jej błąkające się na wszystkie strony podmakają niezmiernie równiny i zamieniają je w niedostępne strugi i błota”.

Inne rzeki analizowanego obszaru płynęły na ogół wyraźnie wyciętymi w podłożu rynnami polodowcowymi. Z XVII- i XVIII-wiecznych map wynika, że szczególnie niżej położone odcinki Samicy i Mogilnicy były dość silnie zabagnione (Hilczerówna, 1967).

Pierwsze próby zahamowania zalewania obszarów zlewni Obry datuje się na 1775 r.; polegały na likwidowaniu spiętrzeń młynów wodnych usytuowanych w wyżej położonych odcinkach rzek, tamujących swobodny przepływ wody. Zlikwidowano wówczas 6 młynów na odcinkach Obry: pod Zbąszyniem, Jaromierzem, Obrą, Kargową i Mosiną, nie uzyskano jednak zakładanych rezulta- 
tów. Dopiero zapoczątkowane w 1799 r. prace melioracyjne w pobliżu Kopanicy i Mosiny, a zwłaszcza wykopanie wzdłuż obrzeży Łęgu kanałów: Północnego i Południowego, a dodatkowo również Kościańskiego, Mosińskiego, Wincentowskiego i kanału Dźwina, przyczyniły się do usprawnienia odpływu wód ze środkowego dorzecza Obry. Prace te trwały do 1806 r. i kosztowały władze pruskie 109253 talary (Archiwum Spółki Melioracji Nizin Obrzańskich).

W latach 1810-1812 przeprowadzono pierwszą gruntowniejszą konserwację kanałów poprzez usunięcie z nich namułów. W okresie 1820-1831 kontynuowano prace melioracyjne - powstał wówczas między innymi Kanał Środkowy, biegnący środkiem Łęgu Obrzańskiego.

Główną sieć rowów oraz uzupełniającą korektę kanałów wykonano po powstaniu w 1842 r. Towarzystwa Melioracji Obrzańskich na podstawie projektu Henninga, obejmującego problemy odwodnienia i nawodnienia terenów przesuszonych. Statut Towarzystwa został podpisany 16 sierpnia 1842 r. w rezydencji Sanssouci przez króla pruskiego Fryderyka Wilhelma. Pierwszym dyrektorem Towarzystwa był Stanisław Chłapowski z Czerwonej Wsi, a od 1850 r. sam generał Dezydery Chłapowski z Turwi, znany z wprowadzenia nowoczesnych metod gospodarowania w rolnictwie. Oprócz budowy kanałów, skupiono się na budowie 13 jazów na głównych kanałach obrzańskich. Działalność Towarzystwa przerwał wybuch I wojny światowej. Po wojnie Towarzystwo działało już zgodnie z postanowieniami Ustawy Wodnej z roku 1922.

Po II wojnie światowej prowadzono generalnie prace konserwacyjne i renowacyjne. Budowa systemu pomp do nawodnień i przerzutów wody pozostała w znacznej mierze w fazie projektów. Prace melioracyjne ograniczały się więc tylko do odwadniania coraz większych obszarów. Choć widziano potrzebę irygacji, odsuwano ją w czasie i zaniedbywano. Spowodowało to osuszanie i zmianę charakteru procesów glebowych, które skutkowały degradacją wielu siedlisk roślinnych (Paluch, 2006).

Meliorowane doliny rzeczne wykorzystywane były przeważnie jako użytki zielone. Jednakże przyjęcie za główny cel w działalności melioracyjnej odwodnienia, bez uwzględnienia rodzajów gleb, spowodowało znaczne zmniejszenie powierzchni łąk. Przesuszone tereny pastwiskowe były zamieniane na grunty orne, dlatego stosunek powierzchni łąk do powierzchni gruntów ornych stale się zmniejszał (Paluch, 2006).

\section{Zmiany sieci hydrograficznej}

\section{Cieki (kanały, rzeki, rowy melioracyjne)}

Z analizy materiałów historycznych, a szczególnie historii Towarzystwa Melioracji Obrzańskich wynika, że środkowe dorzecze Obry podlegało znacznym przemianom. Sieć rzek i strumieni w ciągu minionych wieków podlegała nie tylko naturalnym wpływom środowiska, ale również - zwłaszcza w ostatnich wiekach 
- w dużo większym stopniu celowym działaniom ludności, która, w poszukiwaniu nowych terenów rolniczych i w celu ochrony przeciwpowodziowej już istniejących, prowadziła tu coraz intensywniejsze działania melioracyjne.

Jak przebiegał ten proces, można wnioskować porównując dostępny materiał kartograficzny. W poniższym opracowaniu analizowano długość kanałów i innych cieków obliczoną na podstawie map z trzech przedziałów czasowych: 1826, 1940, 2000. Dla tych trzech okresów można ze sobą porównać jedynie długość kanałów, gdyż na mapach z 1826 r. wyrysowano tylko rzeki i kanały, pozostałe cieki zostały nakreślone zaledwie w niektórych miejscach, a często jakość map uniemożliwiała odczytanie ich przebiegu. Należy jednak mieć na uwadze, że sieć naturalnych cieków została przekształcona tylko w rejonie prowadzonych prac melioracyjnych. Większość dziś istniejących strumieni funkcjonowała już wcześniej.

Jako cieki pochodzenia antropogenicznego przyjęto kanały i rowy. Nieuregulowane odcinki rzek i strumienie uznano za cieki naturalne.

W pierwszej kolejności budowane były kanały, które miały na celu osuszenie wielkich terenów zalewowych. Ich długość wynosiła w poszczególnych latach (ryc. 2 i 3): 86,09 km w 1826, 153,57 km w 1940 i 163,98 km w 2000 r.

Około 52\% długości istniejących kanałów pobudowano do 1826 r., a już w 1940 osiągnięto 94\% dzisiejszego stanu. Przez ostatnie 60 lat część kanałów powysychała i dziś mają one charakter mniejszych rowów. Współcześnie przedłużono już tylko kanał o nazwie Rów Wyskoć.

W drugim etapie przystąpiono do bardziej szczegółowych prac melioracyjnych, a mianowicie budowy uzupełniającej sieci rowów. Intensyfikacja tych prac przypadła na czasy po II wojnie światowej. Upaństwowione gospodarstwa rolne zintensyfikowały prace melioracyjne na tym terenie (ryc. 2).

Długość rowów melioracyjnych w 1940 r. wynosiła 597,27 km (60,9\% wszystkich rowów), a w 2000 - 980,46 km.

\section{Jeziora}

Większość jezior położona jest na południowym wschodzie badanego obszaru, w granicach Pojezierza Krzywińskiego i Wysoczyzny Leszczyńskiej (Kondracki, 2002).

Interesująco kształtują się zmiany liczby i powierzchni jezior w ciągu ostatnich wieków (ryc. 2, tab. 2).

Całkowita liczba jezior zmniejszyła się w badanym okresie o 64\%, jednak ich łączna powierzchnia wzrosła o prawie 11\%. Zdecydowanie większy udział w tych zmianach mają jeziora małe - ich liczba zmniejszyła się o 60\%, a powierzchnia jezior ( $<1$ ha) w sumie o 32\%. Proces ten byłby zapewne wyraźniejszy, gdyby nie powstanie wielu małych zbiorników w miejscach eksploatacji torfu i żwirowniach oraz wykopanie stawów. 
Ogólna powierzchnia zbiorników wodnych na obszarze badań od 1826 do 1940 r. zmalała z 839,4 do 827,3 ha. Od 1940 do 2000 r. nastąpił wzrost łącznej powierzchni jezior do 940,5 ha, głównie wskutek spiętrzenia wód jeziora Wonieść.
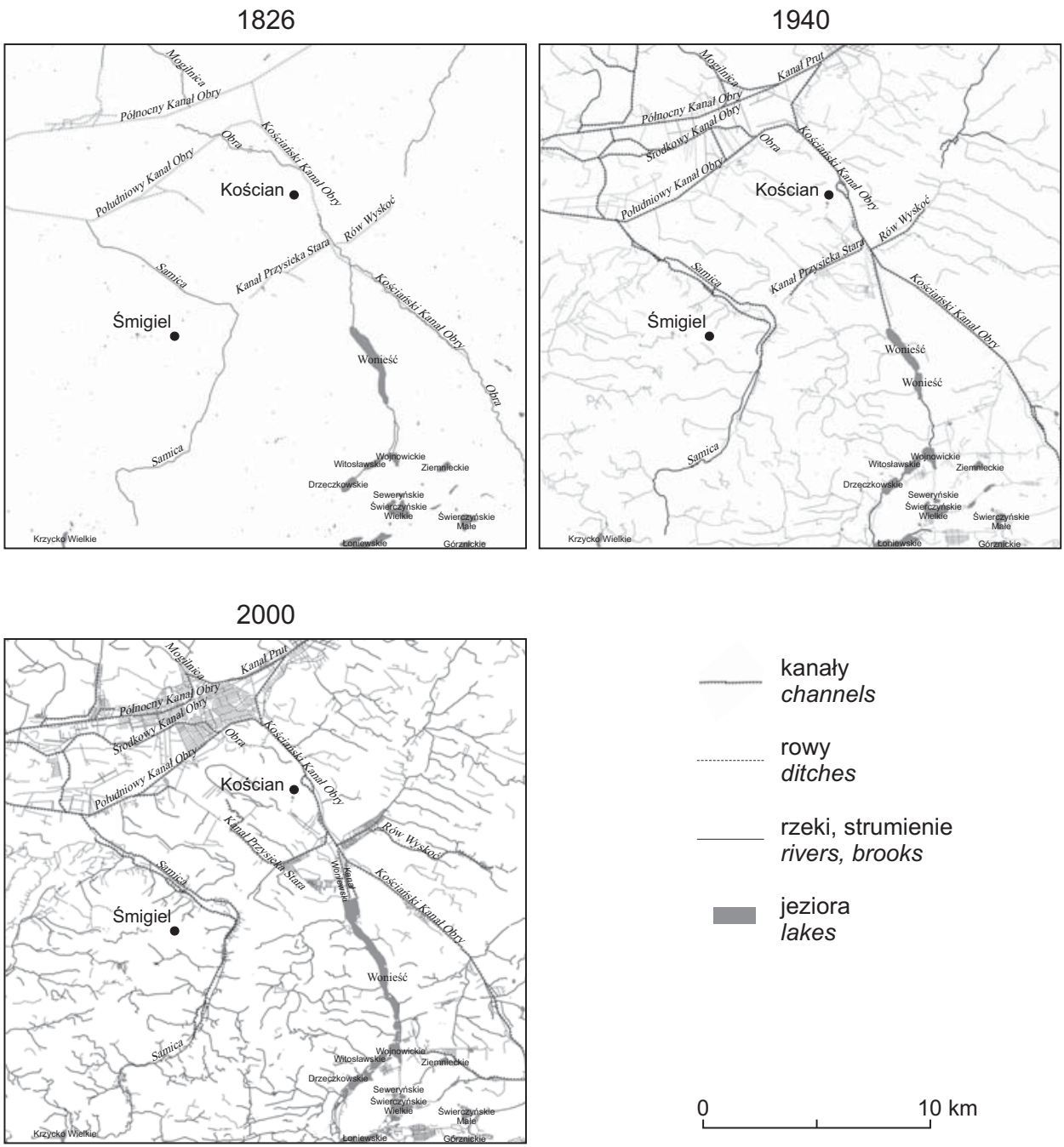

Ryc. 2. Sieć hydrograficzna w latach 1826, 1940, 2000

The hydrographic network in 1826, 1940, and 2000

Powierzchnia tego największego zbiornika wynosiła w 1826 r. 241,9 ha i stanowiła aż 29\% areału wszystkich jezior, w 1940 zaś była mniejsza o 19\% (195,9 ha). W roku 2000 jezioro miało już 368 ha - 52\% więcej niż w 1826 i aż 
88\% więcej w stosunku do 1940 r. Sztuczna zapora spiętrzyła również wody jezior położonych powyżej jeziora Wonieść w tym samym systemie jezior rynnowych: Wojnowickiego, Witosławskiego i Drzeczkowskiego. Tylko te zbiorniki wykazują tendencję wzrostową pod względem powierzchni. Interesującym zjawiskiem był całkowity zanik jeziora na północ od miejscowości Świerczyna - jeszcze w 1940 r. jego powierzchnia wynosiła 11,5 ha, a na mapach z końca XX w. nie było po nim śladu (ryc. 4).

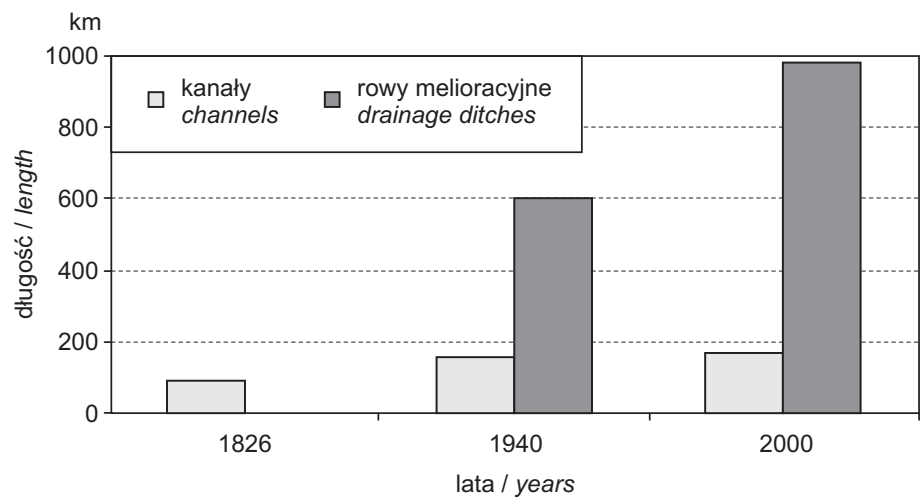

Ryc. 3. Zmiany długości kanałów i rowów

(odnośnie do roku 1826 nie uwzględniono długości rowów melioracyjnych)

Changes in the lengths of canals and ditches

(length of drainage ditches not taken into consideration for 1826)

Tabela 2. Liczebność i powierzchnia jezior

Number and surface area of lakes

\begin{tabular}{|c|c|c|c|c|c|c|}
\hline \multirow{2}{*}{$\begin{array}{c}\text { Lata } \\
\text { Years }\end{array}$} & \multicolumn{5}{|c|}{ Jeziora / Lakes } \\
\cline { 2 - 7 } & \multicolumn{2}{|c|}{$<1$ ha } & \multicolumn{2}{c|}{$>1$ ha } & \multicolumn{2}{c|}{ razem / total } \\
\cline { 2 - 7 } & liczba & powierzchnia & liczba & powierzchnia & liczba & powierzchnia \\
number & area & number & area & number & area \\
\hline 1826 & 220 & 66,2 & 39 & 773,2 & 259 & 839,4 \\
1940 & 157 & 53,4 & 31 & 773,9 & 188 & 827,3 \\
2000 & 131 & 45,2 & 34 & 895,3 & 165 & 940,5 \\
\hline
\end{tabular}

Zanikanie jezior i spadek ich powierzchni stwierdził na podstawie badań historycznych zasobów kartograficznych Wielkopolski A. Kaniecki (1991). Zauważył on, że powierzchnia jezior zmniejszyła się średnio aż o 13\%. Szczególnie wyraźny był zanik małych zbiorników wodnych o powierzchni mniejszej niż 1 ha - na badanych arkuszach map z roku 1890 naliczył 11068 takich jezior, 
w roku 1940 pozostało ich 4873, a w latach 1960. było ich już niespełna 2500 sztuk - w ciągu niespełna stu lat ubyło więc około 75\%. Przyczyny tego upatruje Kaniecki (1991) w działalności człowieka, szczególnie melioracjach i niszczeniu małych śródpolnych zbiorników w celu zwiększenia areału gruntów ornych.

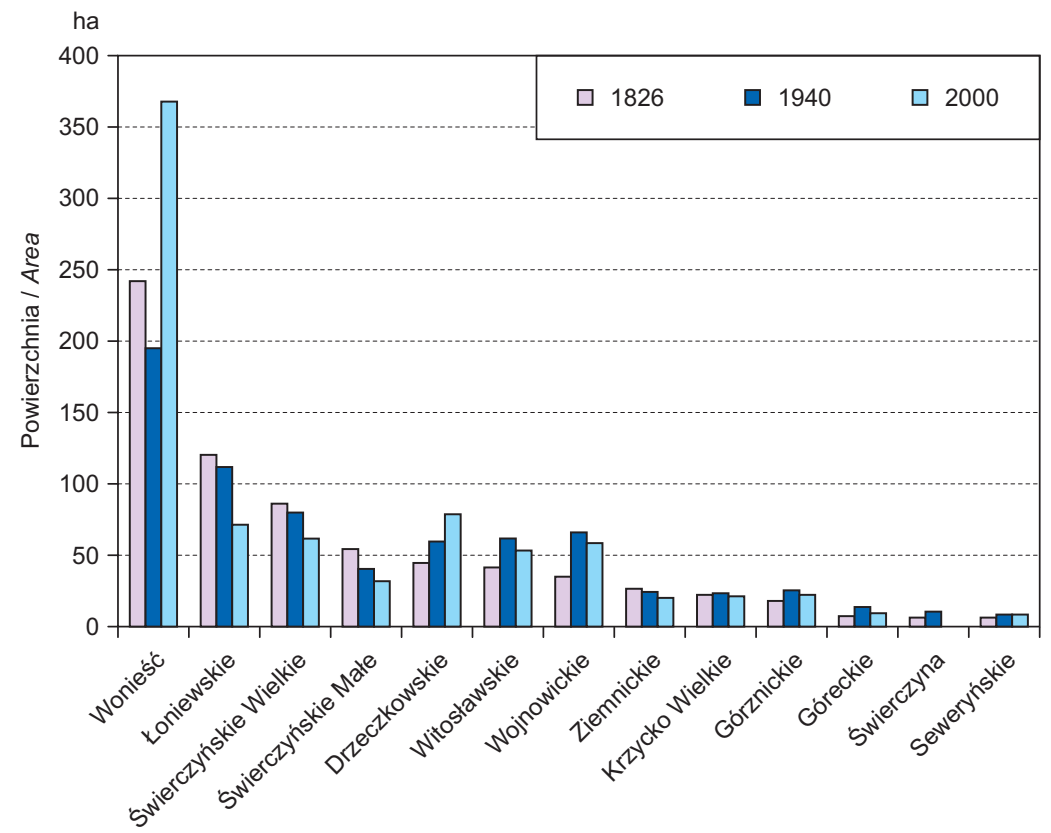

Ryc. 4. Zmiany powierzchni 13 największych jezior

Changes in the area of the 13 biggest lakes

\section{Zmiany powierzchni lasów}

Lasy odgrywają ważną rolę retencyjną w obiegu wody w przyrodzie. Zmniejszenie się powierzchni leśnej spowodowane działalnością gospodarczą człowieka odzwierciedlało się w większej dynamice stanów wody regionu środkowej Obry.

Dane historyczne i kartograficzne dowodzą znacznych zmian przestrzennego rozmieszczenia kompleksów leśnych. Z. Hilczerówna (1967), porównując zrekonstruowane przez K.J. Hładyłowicza (1932) zalesienia w XIV w. z mapa glebową doszła do wniosku, że najdłużej i najsilniej zalesione były obszary gleb bielicowych utworzonych z piasków luźnych i słabogliniastych. Na badanym obszarze większe kompleksy takich gleb znajdowały się na wschód od Krzywinia, na południe od Osiecznej oraz - największy - na południowy zachód od Śmigla. Duże zalesienie potwierdzają liczne nazwy toponomastyczne i rozmieszczenie osadnictwa, które nawet w późnym średniowieczu i w czasach nowożytnych 
omijało tereny zalesione (Hładyłowicz, 1932). Lasem pokryte były nie tylko najsłabsze gleby piaszczyste, lecz również kompleksy gleb zbielicowanych powstałych z gliny zwałowej i piasków naglinowych i naiłowych. Gleby tego typu zajmują duże obszary wysoczyzn. Rosły tu zespoły lasów liściastych i mieszanych z dużym udziałem dębu. W miejscach wilgotnych występował grąd niski, wilgotny, a na terenach suchszych - grąd wysoki, dąbrowa świetlista i bór mieszany (Hilczerówna, 1967).

Doliny rzeczne, pomimo bardziej ożywionej działalności gospodarczej człowieka, także były częściowo zalesione. Krajobraz zbliżony do pierwotnego miały bagna i torfowiska obszarów zalewowych Obry, częściowo zajęte przez olsy i łęgi nadrzeczne (Hilczerówna, 1967).

Rozwój osadnictwa nierozerwalnie związany z potrzebą zdobywania przestrzeni skutkował postępującą wycinką lasów. W Polsce spotęgował ją podział lasów na dobra stołowe i królewskie, które przekazywano w dzierżawę. Upadek państwowości dodatkowo pogorszył sytuację. Czas I i II wojny światowej przyniósł ogromne zniszczenia drzewostanów. Lesistość Polski, która jeszcze pod koniec XVIII w. wynosiła około 40\%, zmalała w 1945 r. do 20,8\%. Dopiero po II wojnie światowej zorganizowane i planowe zalesianie gruntów porolnych i nieużytków doprowadziło do wzrostu lesistości do 27\% w roku 1970. Obecny odsetek lasów to około 28,7\% powierzchni Polski (Białobok, 1971; Błaszczyk, 1974; Wykowski, 2006) (ryc. 5).

Omówiona w pracy analiza materiałów kartograficznych wykazała znaczne zmniejszenie się powierzchni leśnych od 1826 r. Stopień lesistości w każdym z analizowanych okresów był o połowę mniejszy od średniego dla całego kraju. Świadczy to o stosunkowo dużym wylesieniu i przekształceniu omawianego terenu przez człowieka (tab. 3). Trzeba zaznaczyć, że od XIX w. nie odnotowano znaczącego wpływu naturalnych czynników na zmianę warunków siedliskowych, natomiast wpływ działania człowieka jest niewątpliwy.

Budowa kanałów i rowów melioracyjnych spowodowała odwodnienie ogromnych powierzchni i degradację siedlisk łęgowych. Osuszone łęgi karczowano i przekształcano w łąki (Paluch, 2006).

Fragmenty lasów, które istniały zarówno w 1826 jak i w 1940 r. zajmowały $66,85 \mathrm{~km}^{2}$. Powierzchnie porośnięte lasem przez wszystkie 3 okresy poddane badaniu miały w sumie 62,99 km². Największy kompleks - Wielki Łęg Obrzański - który jeszcze w 1826 r. obejmował ogromne obszary, został do 1940 r. bardzo silnie okrojony. Było to zapewne związane z działalnością melioracyjną na tych terenach, która doprowadziła do osuszenia zabagnionej pradoliny.

Spadek lesistości obszarów wysoczyznowych przyczynił się do ograniczenia retencyjnej właściwości lasów, co w konsekwencji doprowadziło do szybszego spływu wód w doliny, a to pogłębiło ich zabagnienie i wymusiło działania melioracyjne. Dochodziło bowiem do corocznych powodzi zimowo-wiosennych i dość częstych powodzi letnich, które najdotkliwiej odczuwano w Dolinie Wielkiego 

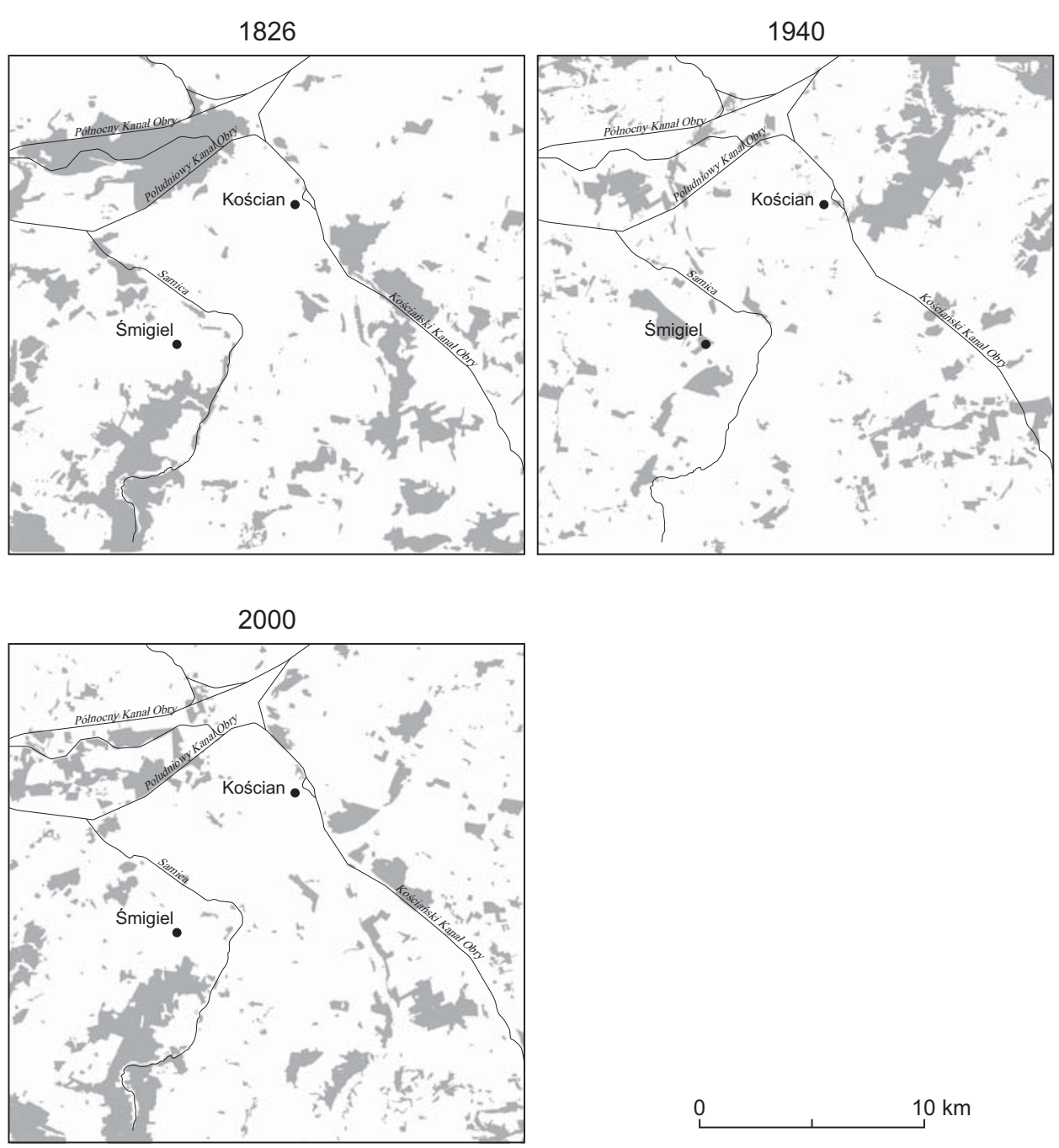

Ryc. 5. Zasięg powierzchni leśnych w latach 1826, 1940, 2000 Forest areas in 1826, 1940, and 2000

Łęgu, gdzie zalewy obejmowały całą dolinę i trwały długo (Przybyła, 2008). W latach 1970. w Biurze Projektów Melioracji Wodnych w Poznaniu opracowano „Studium Generalne Melioracji w Dolinie Kanałów Obry”. Główne kierunki rozwiązań technicznych to: (1) zabezpieczenie doliny Obry przed skutkami powodzi przez rozbudowę kanałów, budowę wałów, pompowni i innych urządzeń technicznych; (2) maksymalne magazynowanie wód w zbiornikach jeziornych i retencyjnych w celu pokrycia deficytów wody. Trzeba pamiętać, że dolina Obry jest położona w obszarze o najniższych w Polsce opadach rocznych, ponadto jest 
regionem intensywnego rolnictwa o dużym potencjale rozwojowym, więc problem magazynowania wody i likwidacji jej niedoborów jest tu istotny.

Tabela 3. Zmiany powierzchni leśnej w badanych latach

Changes in forest area in the studied years

\begin{tabular}{|c|c|c|}
\hline $\begin{array}{c}\text { Lata } \\
\text { Years }\end{array}$ & $\begin{array}{c}\text { Powierzchnia lasów } \\
\text { Forest area } \\
\left(\mathrm{km}^{2}\right)\end{array}$ & $\begin{array}{c}\text { Udział lasów w ogólnej powierzchni } \\
\text { Participation of the total forest area } \\
(\%)\end{array}$ \\
\hline 1826 & 163,39 & 18,69 \\
1940 & 104,80 & 11,99 \\
2000 & 128,74 & 14,73 \\
\hline
\end{tabular}

Dodatkowo analiza kartograficzna potwierdziła, że powierzchnia wspomnianego przez Z. Hilczerównę (1967) kompleksu leśnego na południowy zachód od Śmigla, istniejącego już w XIV w., w ostatnich 200 latach nie uległa znacznym zmianom.

\section{Podsumowanie i wnioski}

Przeprowadzone analizy opisane w pracy pozwalają na wyciągnięcie następujących wniosków.

1. Znaczące zmiany sieci hydrograficznej regionu środkowej Obry dokonały się już w pierwszej połowie XIX w. Do 1826 r. powstało 52\% istniejących do dzisiaj kanałów, a do 1940 r.- 94 \% dzisiejszego stanu długości kanałów.

2. Prace melioracyjne prowadzone w regionie środkowej Obry można podzielić na dwa etapy:

a) druga połowa XVIII i pierwsza połowa XIX w. - odwodnienie Wielkiego Łęgu Obrzańskiego i przekształcenie rzek płynących rynnami glacjalnymi w kanały;

b) okres powojenny to prace konserwacyjne, budowa jazów oraz przede wszystkim budowa gęstej sieci rowów melioracyjnych.

3. Intensywna działalność rolnicza i postępująca wraz z nią melioracja spowodowała w ciągu ostatnich 200 lat zanik 60\% zbiorników wodnych o powierzchni mniejszej niż 1 ha.

4. Potrzebę odwadniania nisko położonych, bagnistych obszarów, oprócz naturalnych uwarunkowań, zwiększało postępujące odlesianie regionu. Skutkiem odlesienia było podnoszenie się zwierciadła wód gruntowych w rynnach glacjalnych i pradolinie (Przybyła, 2008). Lata 1826-1940 przyniosły zmniejszenie lesistości badanego obszaru z 18,69 do 11,99 \%. W okresie powojennym powierzchnia lasów wzrosła dzięki zalesieniom do 14,73\%. Trzeba zaznaczyć, że wszystkie te wskaźniki są o połowę niższe od średniej krajowej w analizowanych przedziałach czasowych. 


\section{Piśmiennictwo}

Białobok S., 1971, Wzrost lesistości i zadrzewienia a bilans wodny, Las Polski, 45, 12, s. 10. Błaszczyk H., 1974, Rozwój lesistości Wielkopolski, Kronika Wielkopolski, 3(4), s. 3-73.

Bykowski J., Kozaczyk P., Mrozik K., Przybyła Cz., Sielska I., 2008, Problemy oceny efektywności ekonomicznej odbudowy i modernizacji urządzeń melioracji podstawowych Kościańskiego kanatu Obry, Zeszyty Problemowe Postępów Nauk Rolniczych, 532.

Bykowski J., Napierała M., 2010, Efektywność ekonomiczna odbudowy i modernizacji urządzeń melioracyjnych Kościańskiego Kanatu Obry w ocenie indywidualnego gospodarstwa rolnego, Zeszyty Problemowe Postępów Nauk Rolniczych, 548, cz. I, s. 89-102.

Bykowski J., Przybyła Cz., 2010, Aktualne problemy funkcjonowania spótek wodnych na przyktadzie działalności Spótki Wodnej Melioracji Nizin Odrzańskich, Zeszyty Problemowe Postępów Nauk Rolniczych, 548, cz. I, s. 103-111.

Dynowska A., 1988, Przemiany stosunków wodnych, [w:] L. Starkel (red.), Przemiany środowiska geograficznego Polski, Ossolineum, Wrocław, s. 137-153.

Graf R., Kaniecki A., Medyńska-Gulij B., 2008, Dawne mapy jako źródło informacji o wodach śródlądowych $i$ stopniu ich antropogenicznych przeobrażen, Badania Fizjograficzne nad Polską Zachodnią, Seria A - Geografia Fizyczna, 59, s. 11-27.

Hilczerówna Z., 1967, Dorzecze górnej i środkowej Obry od VI do początków XI wieku, Wydawnictwo PAN, Wrocław.

Hładyłowicz K.J., 1932, Zmiany krajobrazu i rozwój osadnictwa w Wielkopolsce od XIV do XIX wieku, Badania z Dziejów Społecznych i Gospodarczych, 12, Lwów.

Kaniecki A., 1991, Problem odwodnienia Niziny Wielkopolskiej w ciagu ostatnich 200 lat $i$ zmiany stosunków wodnych, [w:] Materiaty Konferencji „Ochrona i racjonalne wykorzystanie zasobów wodnych w Regionie Wielkopolski”, Poznań, 18 grudnia 1981, Urząd Wojewódzki, Poznań, s. 77-80.

-, 2007, Atrakcyjność starych przekazów kartograficznych dla wspótczesnych badan środowiskowych, [w:] B. Medyńska-Gulij, L. Kaczmarek (red.), Informacja geograficzna w ksztattowaniu i ochronie środowiska przyrodniczego, Bogucki Wydawnictwo Naukowe, Poznań, s. 11-22.

Kaniecki A., Brychcy D., 2010, Średniowieczne mtyny wodne i ich wptyw na przemiany stosunków wodnych na przyktadzie zlewni Obry Skwierzyńskiej, Badania Fizjograficzne nad Polską Zachodnią, 61(1), s. 145-156.

Kondracki J., 2002, Geografia regionalna Polski, PWN, Warszawa.

Kosturkiewicz A., Kędziora A., 1995, Problemy gospodarowania woda na obszarach rolnych, [w:] Ryszkowski L, Bałazy S. (red.), Zasady ekopolityki w rozwoju obszarów wiejskich, PAN, Poznań, s. 73-98.

Krygowski B., 1961, Geografia fizyczna Niziny Wielkopolskiej. Cz. 1. Geomorfologia, PWN, Poznań.

-, 1972, Nizina Wielkopolska, [w:] R. Galon (red.), Geomorfologia Polski, t. 2, Niż Polski, PWN, Warszawa, s. 186-223.

Kurnatowski S., 1968, Osadnictwo i jego rola w kształtowaniu krajobrazu, Folia Quaternaria, 29, s. 183-197.

Lipiński J., 2006, Zarys rozwoju oraz produkcyjne i środowiskowe znaczenie melioracji w świetle badań, Acta Scientarum Polonarum Formatio Circumiectus, 5 (1), s. 3-15.

Mapa hydrograficzna 1:50 000, 2001, arkusz M-33-10-A Leszno-Północ, Główny Geodeta Kraju, Rzeszów. 
Ostromęcki J., 1957, Wstęp do melioracji wodnych, PWRiL, Warszawa.

Paluch J., 2006, Wielkopolskie Spótki Wodne 1842-1918, Rejonowy Związek Spółek Wodnych, Wągrowiec.

Przybyła Cz., 2008, Melioracje rolne (wodne) w Wielkopolsce na przestrzeni dwóch wieków na przyktadzie melioracji w zlewni rzeki Obry, Rocznik Muzeum Narodowego Rolnictwa i Przemysłu Rolno-Spożywczego w Szreniawie, 25, Szreniawa, s. 359-376.

Przybyła Cz., Mrozik K., Bykowski J., Kozaczyk P., Sielska I., 2008, Niedobory wody i potrzeby nawodnień w zlewni Kościańskiego Kanału Obry, Zeszyty Problemowe Postępów Nauk Rolniczych, 532.

Wilgat T., 1991, Zmiany stosunków wodnych pod wptywem gospodarki, [w:] L. Starkel (red.), Geografia Polski - środowisko przyrodnicze, PWN, Warszawa, s. 205-223.

Winiecki A., Drabiński A., 1995, Melioracje a ochrona przyrody - niezbędny kompromis, [w:] L. Tomiałojć (red.), Ekologiczne aspekty melioracji wodnych, Instytut Ochrony Przyrody PAN, Kraków, s. 107-121.

Wykowski J., 2006, Polskie lasy w Europie, Fakty. Magazyn Gospodarczy, 1 (19), styczeń/ luty.

[Wpłynęło: grudzień 2010; poprawiono: czerwiec 2011 r.]

\section{IWONA HILDEBRANDT-RADKE, JAN PRZYBYCIN}

\section{CHANGES IN THE HYDROGRAPHIC NETWORK AND AREA UNDER FOREST IN THE CONTEXT OF THE MIDDLE OBRA MELIORATION (CENTRAL WIELKOPOLSKA REGION),} IN THE LIGHT OF HISTORICAL DATA AND CARTOGRAPHIC MATERIAL

The aim of the thesis has been to assess changes in the drainage system of the middle Obra's catchment area through the summation of surface hydrographical objects at particular periods of time closely related to the available cartographic resources, as well as to compare the lengths of linear objects of the drainage system on the basis of the same materials.

An estimation of the degree to which the drainage system in the region has been changed by human activity in the years 1826, 1940 and 2000 is made.

The same cartographic materials served as the basis for an analysis of the intensity of afforestation, which is a natural retention factor slowing down the flow of precipitation water into a river, and thus controlling the water level of the investigated drainage system.

As far as hydrographic changes are concerned, the surface objects extracted from the digital cartographic materials include lakes and some smaller bodies of water. The linear objects accounted for in the analysis are watercourses, such as canals, rivers and irrigation channels.

The analyses conducted allow the following conclusions to be drawn.

Some significant changes on the watershed map of the middle Obra took place in the first half of the 19th century. 52\% of the canals that have survived to the present day came into being 1826, while as much as $94 \%$ of the present canal length came into existence in or before 1940. 
Irrigation work in the middle Obra region can be divided into two stages. The first one encompasses the second half of the 18th century and the first half of the 19th and relates to the draining of the Great Obra River Wetland and the transforming of the rivers flowing in the old glacial channels into canals. The second stage is the post-War period during which numerous weirs and a dense network of irrigation channels were built.

Intensive agricultural activity and developing irrigation have led, in the last 200 years, to the disappearance of $60 \%$ of the water bodies smaller than 1 ha.

The need to drain boggy lowland wetlands was strengthened by deforestation, which resulted in a raising of groundwater levels in glacial channels and the ice-marginal valley. Between 1826 and 1940 the forest cover in the investigated region declined from $18.69 \%$ to $11.99 \%$. In the post-War period this percentage grew again to $14.73 \%$, thanks to extensive afforestation. It has to be pointed out that these figures represent half of the national average in the analysed periods. 